\title{
Inclusive Educational Environment in Students' Social-Cultural Competence Development
}

\author{
Romanova G.A. \\ Pedagogics Department \\ State Humanitarian -Technological University \\ Orekhovo-Zuevo, Russia \\ galinaromanova3@rambler.ru
}

\begin{abstract}
In terms of social diversity and great attention paid to the problems of people social adaptation, who have disabilities and/or invalidity, and those, who don't have them, increases the significance of students' social-cultural competence. The aim: the model of inclusive educational environment of a higher educational establishment substantiation and description. The model, which is directed toward social-cultural competence development among all categories of students, as one of the inclusion introduction factors. Research methods: overview-analytical method; questionnaire survey among the subjects of educational process, experts examination of educational activity; inclusive educational environment modeling; quantitative analysis of results. Social-cultural competence is presented by a multi-level integrative personal characteristic, which allows organizing communication on the basis of social-cultural interaction. It includes social, personal and activity-based readiness of the subjects for interaction in terms of inclusion and is presented as a range of content-conceptual, behavioral and reflexiveestimating components. The sufficient level of subjects' readiness to accept inclusion was revealed and it was taken into account during the model of inclusive educational environment creation as the factor of students' social-cultural competence development. The author's model is presented by interconnected components: target, contensive, organizational-technological and correctional-regulating. Perspective directions of the model realization were substantiated: social-educational, resource and moderation. Carried out research broadens the range of scientific research works in the context of students' socialcultural competence development problem and also gives new opportunities for effective inclusive educational practices creation and introduction.
\end{abstract}

Keywords—social-cultural competence; inclusive educational environment; students-invalids; disabled students; educational environment modeling.

\section{INTRODUCTION}

Education of invalids and disabled people (DP) in terms of inclusion forms the most optimal condition for their successful socialization, which is proved by the research works of native and foreign scientists.

World experience proves the necessity to give this category of people qualitative education for a full-rate of participation in social life, which is achieved by the opportunity to get a job and promotion of inclusive society [18] on the basis of social model of disability [22]. Inclusion provides social-cultural real interaction organization between students and is directed toward socially important personal characteristics development. One of these characteristics is social-cultural competence. Social-cultural competence development among students, including disabled students, during professional training is one of the successful interpersonal communications factors and personal potentials and all students' demands realization. This problem solution demands special inclusive educational environment modeling at professional colleges and at higher educational establishments. The barriers of inclusive education realization [4], which reflect insignificant level of subjects' readiness to accept inclusion, make the process of effective inclusive environment creation difficult. It is important to create the model of inclusive educational environment and it defines the aim of this research work: to substantiate and describe the model of inclusive educational environment of a higher educational establishment, directed toward social-cultural competence development of all categories of students as one of the factors of inclusion acceptance.

\section{LITERATURE REVIEW}

Educational politics of the USA, Japan and European countries guarantees the availability of professional training for young people with invalidity and disability [2] taking into account their psychological-physiological peculiarities [6], which are known to all subjects of educational process [27]. Educational inclusion is considered as the most important mechanism of social inclusion. These ideas of educational environment social part are widely presented in foreign research works. Professional training provides this category of people inclusion into educational environment, in which their needs, abilities and individual characteristics are realized [9] and innovative forms of correctional support are used [7]. Social effectiveness of inclusive education [1] is possible in terms of "social-professional structure of society development" [8] and accepting invalids and people with disabilities as valuable members of society [36] providing psychological and pedagogical support of inclusive educational process [31], including social adaptation and rehabilitation of students [5]. Qualitative professional and 
higher education and then professional activity are important factors of their successful socialization and a full-rate participation in all spheres of social life. Social experience development of all categories of young people, as U. Sharma and A. Das say, characterizes the effectiveness of inclusive education realization [37], which then guarantees financial independence of graduates with invalidity and disabilities in professional-personal self-actualization. The guarantees of equal access to qualitative education [15] are set by the international declarations and conventions [21], which pay great attention to ethnic groups and the representatives of the countries with low income level [29] in the epoch of educational system digitalization [34]. In students environment the strategies of inclusion are considered as the factors of all students categories success [32].

Nowadays apart from the necessity to provide social equality among all students, stressed by A. Ch. Armstrong, D. Armstrong, I. Spandagou [15], it is important to create innovative approaches to teaching in order to prevent any forms of discrimination concerning disabled people [38] and the ideas, mentioned by European agency of special and inclusive education development, promotion [20]. These approaches condition different forms of mutual education organization [30]. It is important, in the opinion of D. Hill и D. Brown, to involve students with disabilities into the process of aims setting and group decision making and also develop their skills of work self-organization [24] in inclusive educational environment, when the participants are ready to transfer from the traditional system of education 25] to broadening the participation of all subjects in education [35] and life of students with disabilities.

The success of socialization process, personal and educational needs development of invalids and people with disabilities depends on the attitude of all subjects of educational process to this category of people. In this case we deal with insufficient readiness of subjects of educational process to inclusion, the result of which is educational society creation, which is ready to support students with disabilities and encourage high results [19], achieved by all interested people [28] during the process of social experience gaining. This category of people acceptance by society is combined with the readiness to work in new conditions [13], where all subjects of educational process respect the individuality of the culture and cultural diversity of students $[16 ; 17]$.

Inclusive educational process is oriented towards socialcultural dynamics [1], which provides experience improvement concerning, in the opinion of $\mathrm{C}$. Forlin and $\mathrm{T}$. Loreman, social-cultural context of students [21], which helps to accept the characteristics of multicultural society [10] with all its social-cultural traditions [29]. In this connection, in the opinion of E. L. Shackelford and M. Edmonds, it is important to take into account cultural differences and individual peculiarities of the process of interpersonal communications at all levels of education [36]. It is mentioned that social-cultural context plays the main role in defining the fact, whether there is inclusive education in several regions and countries of the world [30] or not, including developing countries [29]. Nowadays one of the priorities is teaching foreign students in terms of inclusion
[23]. A. Soorenian underlines the importance of inclusive practices in terms of internationalized system of education during professional training, but at the same time he underlined the insufficient character of normative-juridical and methodical support, which is necessary for successful inclusion of disabled students into educational process [38]. These peculiarities also prove insufficient readiness of educational process subjects at professional colleges and higher educational establishments to successful organization of social interaction of students and disabled students.

Strategy of inclusive education is directed not only toward professional competencies mastering, but also toward socialcultural competence mastering, high level of which proves effective integration of invalids and disabled people into society. The formed competence is considered as intellectually and personally conditioned social-professional characteristic [3] and as the graduate's competencies realization [12], which describes motivated skills [33] and the range of personal qualities, which are necessary for personal socially important productive activity realization [14]. At the same time, the stress is on personal human development as the subject of inclusive social-educational environment and as the personality, who has culture-oriented way of behavior in society [11]. Otherwise we can't speak about effective inclusive educational environment modeling, which has to develop social-cultural competence of all students categories in the system of professional colleges and higher education. The structure of social-cultural competence of educational inclusion subjects can be offered as the range of contentconceptual, behavioral and reflexive-estimating components.

Literature analysis concerning theory and practice of inclusive education in Russia and foreign countries proves that insufficient attention is paid to the questions of readiness of educational environment subjects for inclusion as an optimal form of mutual education of disabled students and normative students. We also speak about readiness to develop social-cultural competence as an important personal characteristic, which conditions success of interpersonal communications in terms of multicultural society of educational inclusion.

\section{RESEARCH METHODOLOGY}

The model of inclusive educational environment substantiation and description is connected with studying readiness of educational environment to develop students' social-cultural competence. The directors and pedagogical staff, different categories of students, parents of students at professional colleges and higher educational establishments in Moscow region took part in the research work. General volume of sampling was 626 people, 262 of which are directors and pedagogical workers, 290 students (including 27 students-invalids and 38 disabled students), 74 parents (including 22 parents of students-invalids and disabled students).

In studying readiness level among the directors and pedagogical staff to develop students' social-cultural competence in terms of inclusive educational environment we used the author methodologies, which analyze objectivespatial, social and activity-based higher educational 
establishment environment organization [10]. The key point of the methodology of diagnosis is the author's questionnaire, which has 3-point scale of estimation (low, average and high level of the diagnosed parameter). This questionnaire reflects the following parameters of readiness for professional development of students' social-cultural competence:

- $\quad$ knowledge of the basis of special psychology and correctional pedagogics;

- knowledge of psychological-physiological characteristics in accordance with the kind of disability;

- knowledge of the peculiarities (pedagogical technologies) of interaction with disabled students and their parents;

- $\quad$ emotional acceptance of disabled students;

- $\quad$ the ability to involve disabled students into mutual activity;

- $\quad$ knowledge of the students' individual educational route projection technologies and the ability to create it.

Readiness diagnostics among the directors and pedagogical staff for professional development of students' social-cultural competence in terms of inclusive educational environment is also realized with the help of studying methodical projects of curator plans and meetings with parents.

A questionnaire survey among all participants of the educational process is held according to the following aspects: necessary knowledge concerning this problem (according to different nosologies); positive motivation for this form of education; readiness to realize mutual activity; knowing the ways, models of interaction.

\section{RESULTS}

As results of review-analytical method use we gave the characteristic to inclusive educational environment, which provides professional development of students' socialcultural competence.

In the context of the studied problem social-cultural competence is considered as a personal characteristic, determined by psychological readiness to realize cooperation during different problems solution, necessary socially significant moral-ethical mindsets and personality's qualities.

Target component of the model is directed toward strategic aim, tactical objectives setting and operative actions concerning inclusive educational environment creation, which provides professional development of social-cultural competence among all categories of students as the main aim of the model. Tactical objective is readiness determination of educational process subjects to inclusion acceptance in the system of professional colleges and higher educational establishments.

Contensive component of the model is directed toward cognitive part of this system formation and theoretical aspects formation of interaction between the subjects of educational process in the context of the considered problem. This component includes the characteristics of inclusive educational environment, which provides students' social-cultural competence development during their professional training; the content of social-cultural competence, presented in a form of the parts of subjects' readiness to realize inclusion and the criteria of their formation level at the stages of studying inclusive educational environment: vertical and horizontal. Organizationaltechnological component includes the main approaches and principles of life realization among the subjects of educational relations in terms of inclusive educational environment.

Correctional-regulative component provides the model regulation and correction, regulates activity between all components in the set aim achievement.

Control-estimating component is directed toward the activity effectiveness analysis and estimation according to the main components of the model, the problems of its realization revelation and the resources of their leveling, conditions "a new turn" of model activity as a system. The following directions of the model realization were created: social-educational, resource and moderation.

Social-educational direction content includes socialpsychological education, consulting, psychological-pedagogical support; communication trainings, personal growth trainings among all subjects of educational relations.

The essence of moderation is in the system of conditions creation and realization and inclusive educational environment of professional colleges and higher education influence, directed toward students' social-cultural competence development; instruments (mechanisms, techniques, ways, technologies, ways of development, methodical support of professional development process on the basis of inclusion) development; activity projection and prediction; functional interconnection provision between all components of the model; information-methodical help organization.

Resource direction is aimed at the search and actualization of the complex of necessary external and internal resources of inclusive educational environment as the system in the planned results achievement - students' social-cultural competence development during professional training.

The characteristics of the studied educational environment are defined in the research work. These characteristics correspond with the main level of educational process subjects' readiness to accept inclusion during professional training. The characteristics reflect professional personal qualities study, attitude to inclusive educational environment at professional colleges and higher educational establishments and readiness to realize interpersonal communications in terms of inclusive educational environment. On the other hand, these characteristics correspond with the reconsidered content of social-cultural readiness of students, which includes personal, social and psychological readiness. 


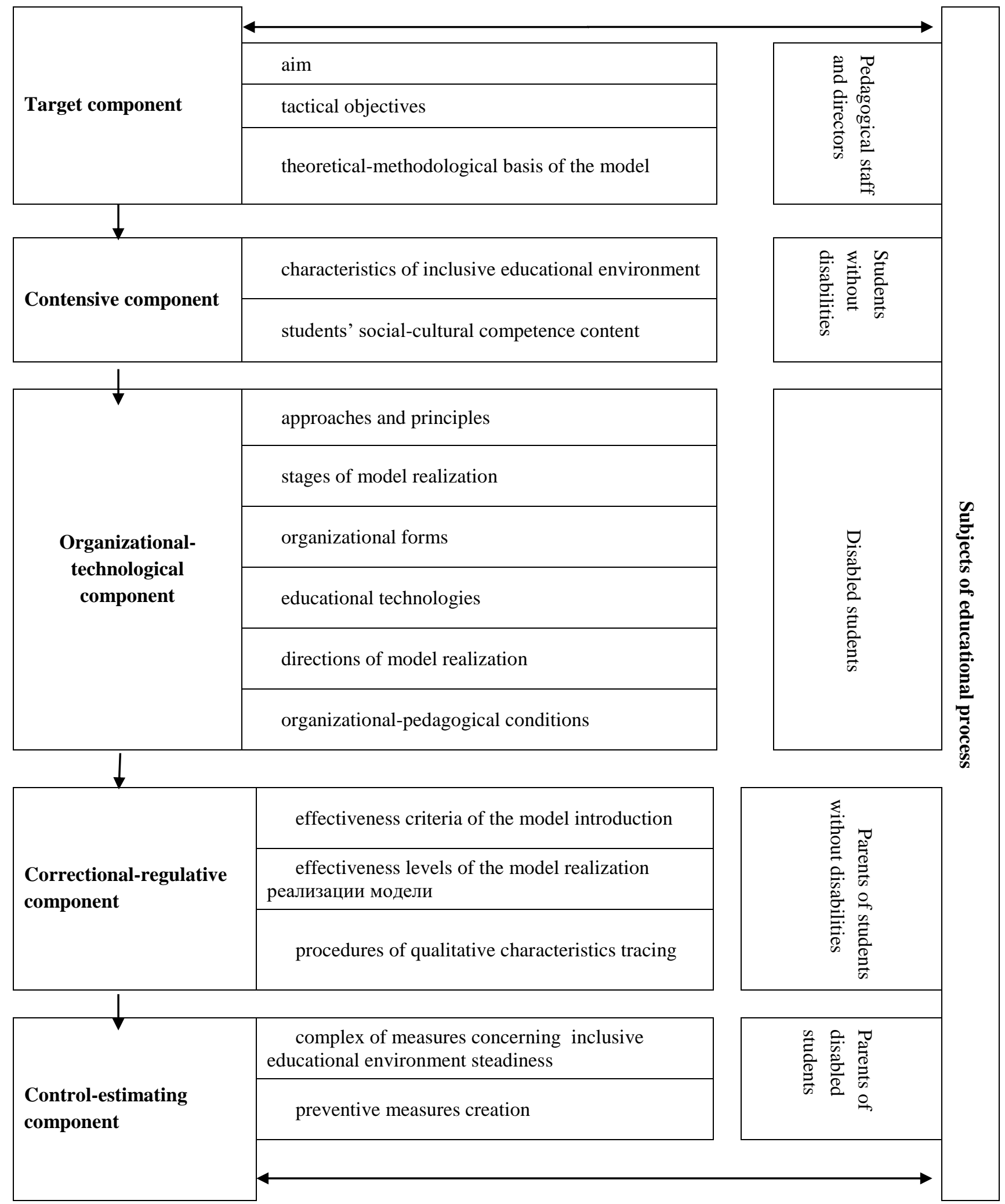

Fig. 1. Inclusive educational environment model, which provides professional development of students' social-cultural competence

\section{CONCLUSION}

The aim of inclusive educational environment functioning at professional colleges and higher educational establishments becomes not only training a student, who has the definite level of competence for successful work gaining and professional 
self-realization, but also student's persona; development as the subject of multicultural society, able to realize effective interpersonal communication in terms of social inclusion as an objective reality.

Insufficient level of readiness to professional development of students' social-cultural competence, revealed as a result of author's diagnostics, substantiated the necessity to authors modeling of inclusive educational environment. Taking its characteristics into consideration and the reconsidered content of the initial cpmpetence, which is presented by social, personal and psychological kinds of readiness, helped to create the model-scheme of the corresponding process, which reveals professional-personal qualities, attitude to inclusive educational environment and readiness to interpersonal communications study in terms of inclusive educational environment at professional colleges and higher educational establishments.

Modeling inclusive educational environment, which provides professional development of social-cultural competence among students, is presented by the following components: target, contensive, organizational-technological, correctional-regulating and control-estimating. The studied modeling processes substantiation and description is necessary for all subjects of educational process, who work and study at professional colleges and higher educational establishments both in Russia and abroad. As foreign and native experience of educational inclusion realization demands development, then the received research results would enrich international theory and practice of professional training among disabled students.

\section{References}

[1] Alekhina S.V. Inclusive education: from politics to practice Psychological science and education. 2016, vol. 21, 1, pp. 136-145 URL: http://psyjournals.ru/files/81000/pno_2016_n1_alekhina.pdf

[2] Boginskaya Y.V. Modern state of higher education among disabled students at higher educational estbalishments of Europe and the USA. World of science. 2016, vol. 4, 4. URL:http://mirnauki.com/PDF/35PDMN416.pdf

[3] Zimnyaya I.A. Competence and competence in the context of competence based approach in education. Scientific notes of the National society of the applied linguistics. 2013, 4(4), pp. 16-31.

[4] Zorina E.E. Barriers overcoming during inclusive education realization at a higher educational establishment. Education and science. 2018, 20(5), pp. 165-184. doi:10.17853/1994-5639-2018-5165-184

[5] Malofeev N. N. Inclusive education in the context of modern social politics. Upbringing and education of children with development disorder. 2009, 6, pp. 3-9.

[6] Martynova E.A., Romanenkova D.F., Romanovich N.A. Inclusive education organization among invalids and disabled people in professional educational establishments: manual. Chelyabinsk: Polygraph-Master. 2016, 101.

[7] Nigmatullina I.A. Inclusive psychology - innovative direction of training masters (the future specialists in psychology). Inclusive professional education: materials of All-Russian scientific-practica conference, Chelyabinsk, November, 21-22. 2014. Chelyabinsk: Chelyabinsk State University publishing house. 2015, pp. 17-21.

[8] Romanov P.V., Yarskaya-Smirnova E.R. Politics of invalidity: social citizenship in modern Russia. Saratov: Publishing house "Scientific book". 2006, 260.

[9] Romanova G.A.Inclusive educational environment modeling at a higher educational establishment and its problems. Inclusion in education. 2017, 2(2), pp. 48-57.

[10] Romanova G.A. Readiness determination of a higher educational establishment to the environment creation of social-cultural competence development among students in terms of inclusion. Problems of modern pedagogical society. 2017, 55(6), pp. 175-184.

[11] Samokhvalova I.G. Social-cultural competence of a personality. Pedagogical education in Russia. 2012, 2, pp. 71-74.

[12] Frolov Y.v., Makhotin D.A. Competence based model as the basis of specialists' quality of training estimation. Higher education today. 2004, 8, pp. 34-41.

Khitruk V.V. Inclusive readiness formation among the future [13] teachers: didactic model effectiveness. Bulletin of Baltic federal University named after I. Kant. Series: Philology, pedagogics, psychology. 2015, 5, pp. 112-120.

Khutorskoi A.V. Key competencies as the component of person-

[14] oriented paradigm of education. Public education. 2003, 2, pp. 5864.

[15] Armstrong A.Ch., Armstrong D., Spandagou I. Inclusive education International policy \& practice. SAGE Publications Ltd. 2010, 176. doi:10.4135/9781446221990

[16] Barton L., Slee R. Competition, selection and inclusive education: Some observations. International Journal of Inclusive Education. 1999, 3(1), pp. 3-12. doi:10.1080/136031199285147

[17] Booth T., Dyssegaard, B. Quality is not enough. The contribution of inclusive values to the development of education for all. Canterbury. $2015 . \quad$ URL: https://www.eenet.org.uk/resources/docs/QualityIsNotEnough.pdf

[18] Bualar T. Barriers to inclusive higher education in Thailand: Voices of blind students. Asia Pacific Education Review. 2017, pp. 1-9. doi:10.1007/s12564-017-9512-7

[19] Centre for Studies on Inclusive Education. Index for inclusion: Developing learning and participation in schools. 20 May 2018. URL: explained.shtml

http://www.csie.org.uk/resources/inclusion-index-

[20] European Agency for Special Needs Education and Inclusive Education. Inclusive education for learners with disabilities: Brussels: European Parliament. 2017, 46.

[21] Forlin C., Loreman T. (Eds.) Measuring inclusive education Bingley, UK: Howard House. 2014, 329.

[22] Genova A. Barriers to inclusive education in Greece, Spain and Lithuania: Results from emancipatory disability research. Disability \& Society. 2015, 30(7), pp. 1042-1054. doi:10.1080/09687599.2015.1075867

[23] Gualtieri T. Ties that bind: International students at a Christian University. Higher Education in Russia and Abroad. 2017, 2(12), pp. 9-10.

[24] Hill D., Brown D. Supporting inclusion of at risk students in secondary school through positive behaviour support. International Journal of Inclusive Education. 2013, 17(8), pp. 868-881. doi:10.1080/13603116.2011.602525

[25] Inclusive education in Europe: Putting theory into practice: Proceedings of the International Conference, Odense, Denmark, 18 November 2013. Brussels: European Agency for Special Needs and Inclusive Education. 2014, 100.

[26] Joint report of the Council and the Commission on the implementation of the strategic framework for European cooperation in education and training (ET 2020) - New priorities for European cooperation in education and training. Official Journal of the European Union. 2015. URL: https://eurlex.europa.eu/legal-

content/EN/TXT/?uri=celex:52015XG1215\%2802\%29

[27] Kendall L. Higher education and disability: Exploring student experiences. Cogent Education. 2016, 3, pp. 1-12. doi:10.1080/2331186X.2016.1256142

[28] Krauskopf K., Knigge M. Case by case - Promoting teacher students' beliefs about multi-professional and Teacher-Parent collaboration by systematic case reflection (kollegialeFallarbeit) New international perspectives on future teachers' professional competencies: International Congress within the frame of the QualitätsoffensiveLehrerbildung. Universität Hamburg. 2017.

[29] Mariga L., McConkey R., Myezwa H. Inclusive education in lowincome countries: A resource book for teacher educators, parent trainers and community development workers. Cape Town: Atlas Alliance and Disability Innovations Africa. 2014, 136. 
[30] Mitchell D. What really works in special and inclusive education: Using evidence-based teaching strategies. $2^{\text {nd }}$ ed. London, New York: Routledge. 2014, 253.

[31] Morgado B.,Cortés-Vega M. D., López-Gavira R., Álvarez E., Moriňa A. Inclusive education in higher education? Journal of Research on Special Educational Needs. 2016, 16(s1), pp. 639-642. doi:10.1111/1471-3802.12323

[32] Nguyen X.Th. The journey to inclusion. Rotterdam, Netherlands: Sense Publishers. 2015, 199.

[33] Raven J. Competence in modern society: Its identification, development and release. Unionville, New York: Royal Fireworks Press. 1997, 268.

[34] Rayner S. Managing special and inclusive education. SAGE Publications. 2007, 232. doi:10.4135/9781446213032

[35] Reinders H.S. The power of inclusion and friendship. Journal of Religion, Disability \& Health. 2011, 15(4), pp. 431-436. URL: http://www.tandfonline.com/doi/full/10.1080/15228967.2011.6193 41

[36] Shackelford E. L., Edmonds M. Beyond disability: Etiquette matters. Bloomington, IN: Xlibris. 2014.

[37] Sharma U., Das A. Inclusive education in India: Past, present and future. Support for Learning. 2015, 30(1), pp. 55-68. doi:10.1111/1467-9604.12079

[38] Alexsandr S. Kuznetsov. Russian Professor's meeting. Russian Journal of Physical Education and Sport. 2019, 14(1), pp. 17-22. DOI: $10.14526 / 2070-4798-2019-14-1-18-24$

[39] Soorenian A. Disabled international students in British higher education: Experiences and expectations. Rotterdam, Netherlands: Sense Publishers. 2013, 232. 